\title{
PENGARUH EKSTRAK BUAH MENGKUDU TERHADAP MORTALITAS ULAT GRAYAK (Spodoptera litura F.)
}

\section{Endhy Nura Prassetia Mega*, Dedi Supriyatdi, dan Albertus Sudirman}

Program Studi Produksi dan Manajemen Industri Perkebunan Jurusan Budidaya Tanaman Perkebunan, Politeknik Negeri Lampung,

Jl. Soekarno-Hatta No. 10 Rajabasa, Bandar Lampung, 35144

Telp (0721) 703993 Fax (0721) 78730

*E-mail: egavivo549@gmail.com

\begin{abstract}
ABSTRAK
Ulat grayak (Spodoptera litura F., Lepidoptera, Noctuidae) adalah hama daun yang menghambat tanaman karena mengandung polifag. Kisaran tanaman yang menyebabkan S. litura sebagai hama utama di berbagai jenis tanaman seperti perkebunan, buah, sayuran, tanaman pangan. Rentang tembakau, kol, ubi jalar, kentang, kedelai, dan lainnya. Serangan $S$. litura dengan menempelkan daun sampai epidermis tipis keluar pada permukaan daun dan tulang daun. Tumbuhan yang dapat dijadikan bahan baku insektisida nabati adalah buah mengkudu (Morinda citrifolia L.). Insektisida adalah campuran kimia atau kimia yang digunakan untuk mengendalikan hama tanaman (OPT). Insektisida digunakan sebagai cara untuk mengendalikan hama dan menyelamatkan tanaman. Penggunaan insektisida sintetis memiliki beberapa efek negatif pada lingkungan. Salah satu efek negatif lain dari insektisida sintetik adalah adanya resistensi hama $S$. litura terhadap insektisida yang diberikan. Tujuan dari penelitian ini adalah untuk mempelajari potensi besar buah mengkudu sebagai insektisida tanaman dalam pergerakan hama $S$. litura dan alat ukur terbaik dari insektisida nabati ini. Penelitian dilakukan di Laboratorium Tumbuhan, Departemen Budidaya Tanaman, Politeknik Negeri Lampung, pada Oktober 2018 hingga Desember 2018. Desain penelitian menggunakan Rancangan Acak Lengkap (RAL) dengan 4 ulangan. Bahan baku yang digunakan adalah buah mengkudu matang. Insektisida nabati dibuat dari ekstrak buah mengkudu dalam mengendalikan hama S. litura dan konsentrasi terbaik terjadi pada P1 dengan konsentrasi ekstrak $100 \%$.
\end{abstract}

Kata kunci: Ekstrak mengkudu, ulatg rayak, insektisida nabati.

\section{ABSTRACT}

Caterpillar (Spodoptera litura F., Lepidoptera, Noctuidae) is a leaf pest that inhibits plants because it contains polyphags. The range of plants that causes $\underline{S}$. litura as the main pest in various types of plants such as plantations, fruit, vegetables, food plants. The range of tobacco, cabbage, sweet potatoes, potatoes, soybeans, and others. S. litura attacks by sticking the leaves until thin epidermis come out on the leaf surface and leaf bones. Plants that can be made as raw materials for plant-based insecticides are ripe mengkudu fruit (Morinda citrifolia L.). An insecticide is a chemical or chemical mixture used to control plant pests (OPT). Insecticides are used as a way to control pests and 
save crops. To overcome this, another alternative is needed to use synthetic insecticides, taking into account some negative environmental effects. One of the other negative effects of synthetic insecticides is that there will be resistance to $\underline{S}$. litura pests against insecticides. The purpose of this study is to study the great potential of mengkudu fruit as a plant insecticide in the movement of $\underline{S}$. litura pests and the best measuring tool from these vegetable insecticides. The study was carried out at the Plant Laboratory, Department of Plant Cultivation, Lampung State Polytechnic, in October 2018 to December 2018. The research design used a Completely Randomized Design (RAL) with 4 replications. The raw material used is ripe mengkudu fruit. Vegetable insecticide made from ripe mengkudu fruit extract in controlling $\underline{S}$. litura pests and the best concentration occurs in P1 with $100 \%$ extract concentration.

Key words: Mengkudu ripe fruit, carterpillar, vegetable insecticide.

\section{PENDAHULUAN}

Ulat grayak (Spodoptera litura F.) merupakan salah satu hama penting yang harus dikendalikan dengan serius, serangan larva $S$. litura menyebabkan kerusakan sehingga petani merugi (Lestari et al.2013). Kisaran inang yang luas menyebabkan $S$. litura berpotensi sebagai hama utama pada banyak jenis tanaman seperti perkebunan, buah, sayuran, tanaman pangan. Kisaran inang meliputi tembakau, kubis, ubi jalar, kentang, kedelai, dan lainnya. S. litura menyerang dengan cara memakan daun hingga tersisa epidermis tipis pada permukaan daun dan tulang daun. Serangan S. litura mengakibatkan kehilangan atau menurunnya hasil perkebunan para petani.

Insektisida merupakan suatu bahan kimia atau campuran dari beberapa bahan kimia yang digunakan untuk mengendalikan Organisme Pengganggu Tanaman (OPT). Pengendalian OPT memiliki hubungan dengan beberapa jenis pestisida seperti insektisida, fungisida, dan nematisida yang cukup dikenal oleh petani. Kegiatan budidaya yang baik dilaksanakan dengan cara menggunakan bibit unggul, pemupukan, dan insektisida (Wiratno et al., 2013). Insektisida digunakan sebagai salah satu cara untuk mengendalikan OPT dan menyelamatkan hasil panen.

Penggunaan insektisida sintetis saat ini semakin pesat digunakan oleh para petani untuk mengendalikan hama. Peningkatan kebutuhan sandang, pangan, dan papan, menuntut petani untuk semakin memaksimalkan penggunaan lahan. Insektisida sintetis memiliki dampak negatif terhadap lingkungan dan kesehatan manusia. Residu yang ditinggalkan oleh insektisida sintetis setelah pemakaian akan berada dalam tanah hingga bertahun-tahun, hal itu berdampak pada mikroorganisme tanah.

Pengendalian hama yang baik yaitu dengan menerapkan Pengendalian Hama Terpadu (PHT) dimanapenggunaan insektisida hendaknya menjadi pilihan terakhir (Thamrin et al.). Ancaman hama $S$. litura perlu diatasi dengan pengetahuan terkait dengan biologi S. litura, tingkat kerusakan dan teknik pengendalian. Alternatif lain diperlukan untuk menggantikan penggunaan insektisida sintetis, mengingat ada banyak dampak negatif pestisida tersebut terhadap lingkungan. Salah satu dampak negatif dari insektisida sintetis yaitu terjadinya resistensi pada hama $S$. litura terhadap insektisida. Populasi hama S. litura yang resisten terhadap insektisida tidak lagi berpengaruh pada mortalitas hama. Alternatif yang dapat dilakukan adalah dengan menggunakan insektisida nabati.

Penggunaan insektisida nabati memiliki banyak keuntungan seperti tidak berbahaya bagi pengguna, ramah lingkungan, bahan baku insektisida 
mudah ditemukan di alam dan biaya lebih murah dibandingkan dengan insektisida sintetis. Petani harus mengembangkan insektisida yang ramah lingkungan, dengan cara memanfaatkan tanaman yang ada di alam sebagai bahan baku insektisida nabati. Salah satu bahan baku untuk membuat insektisida nabati yaitu buah mengkudu matang.

Berdasarkan uraian dan penjelasan di atas, maka dilakukan penelitian terkait uji efektivitas ekstrak buah mengkudu matang sebagai insektisida nabati pada mortalitas larva S.litura.

\section{METODE}

Penelitian dilaksanakan di Laboratorium Tanaman, Jurusan Budidaya Tanaman Perkebunan, Politeknik Negeri Lampung, pada Oktober 2018 sampai dengan Desember 2018. Alat yang digunakan pada penelitian yaitu blender, timbangan Ohaus, kuas kecil, pinset, ember plastik, gelas ukur, pisau, saringan kain, pengaduk, botol mineral, gelas plastik, cawan petridisk dan kurungan serangga. Sedangkan bahan yang digunakan pada penelitian yaitu buah mengkudu matang, gula merah, kapas, serbuk gergaji, madu, bioaktivator (EM4), air, telur S. litura, dan daun bayam.

Penelitian menggunakan Rancangan Acak Lengkap (RAL) dengan 4 ulangan. Bahan baku insektisida nabati yang digunakan terdiri dari buah mengkudu matang, yang terdiri dari 5 perlakuan dan 1 perlakuan kontrol dengan menggunakan aquades. Pada $\mathrm{P}_{1}$ larva yang berada di gelas plastik atau cawan petridisk diaplikasikan dengan ekstrak buah mengkudu matang $100 \%$, pada $\mathrm{P}_{2}$ larva yang berada di gelas plastik atau cawan petridisk diaplikasikan dengan ekstrak buah mengkudu matang 80\%, pada $\mathrm{P}_{3}$ larva yang berada di gelas plastik atau cawan petridisk diaplikasikan dengan ekstrak buah mengkudu matang $60 \%$, pada $\mathrm{P}_{4}$ larva yang berada di gelas plastik atau cawan petridisk diaplikasikan dengan ekstrak buah mengkudu matang $40 \%$, pada $\mathrm{P}_{5}$ larva yang berada di gelas plastik atau cawan petridisk diaplikasikan dengan ekstrak buah mengkudu matang 20\%, dan pada $\mathrm{P}_{0}$ perlakuan kontrol. Larva yang berada di gelas plastik atau cawan petridisk diaplikasikan dengan aquades $100 \%$, dengan 4 ulangan dan 6 perlakuan sehingga terdapat 24 satuan percobaan. Data yang diperoleh diolah dengan menggunakan analisis ragam jika terdapat perbedaan dilanjutkan dengan Uji Duncan $\alpha=0,05$.

Cara menghitung mortalitas larva $S$. litura dapat menggunakan rumus sebagai berikut :

$$
\mathrm{M}=\frac{n}{N} x 100 \%
$$

Keterangan :

$\mathrm{M}=$ Mortalitas larva

$\mathrm{n}=$ Jumlah larva yang mati

$\mathrm{N}=$ Jumlah seluruh larva yang diamati

Data mortalitas larva dianalisa dengan sidik ragam. Jika terdapat perbedaan diantara nilai tengah maka dilanjutkan dengan Uji Duncan $\alpha=0,05$.

Benih bayam disemai langsung pada lahan yang telah dipersiapkan. Bayam yang telah disemai kemudian ditutup dengan mulsa dari jerami padi. Lahan diolah hingga gembur dan diberi pupuk kandang dengan perbandingan volume 1:1. Setelah berumur sekitar 2 Minggu tanaman bayam dipupuk dengan pupuk NPK. Penyiraman dilakukan dengan teratur. Pemeliharaan dilakukan setiap hari, meliputi penyiraman, penyiangan gulma, dan pengendalian hama secara mekanis. Setelah tanaman bayam berumur sekitar 1 bulan, daunnya dapat digunakan sebagai pakan larva S. litura .

Tanaman mengkudu yang dijadikan sebagai bahan baku insektisida nabati yaitu buah mengkudu matang, memiliki kriteria warna buah kuning, berbau menyengat, dan buah lunak. Bahan baku dicuci terlebih dahulu sebelum 
digunakan atau dijadikan insektisida nabati. Kemudian untuk buah mengkudu matang diambil daging buahnya. Hal tersebut dilakukan untuk mempermudah proses penghalusan yang dilakukan di Laboratorium Tanaman, Politeknik Negeri Lampung.

Uji mortalitas yang digunakan dalam pengujian yaitu larva $S$. litura instar kedua pada generasi kedua yang merupakan hasil perbanyakan di Laboratorium Hama. Larva S. litura ditempatkan dalam gelas plastik sebagai wadah yang telah diisi dengan kain kasa. Pada tahap perbanyakan larva $S$. litura diberi pakan bayam alami setiap 2 kali dalam sehari tanpa diberi perlakuan. Pakan diganti dengan bayam segar dan kotoran larva dibersihkan menggunakan kuas.

Pemberian serbuk gergaji sebagai media pada tempat atau wadah larva yang bertujuan untuk perkembangan larva menjadi pupa. Larva yang telah menjadi pupa ditempatkan pada wadah gelas plastik yang lebih besar beralaskan kertas saring. Pupa yang telah terkumpul dan ditempatkan pada wadah dengan jumlah pupa kurang lebih 25 pupa setiap gelas. Kemudian pupa yang menjadi imago ditaruh dan dipelihara pada kurungan khusus serangga hingga menghasilkan telur.

Imago S. litura diberi pakan berupa cairan madu yang diserapkan pada kapas. Di dalam kandang diberi 2-3 helai daun bayam yang pada ujung tangkai daun diikat menggunakan kapas basah agar daun tidak mudah layu. Daun tersebut diharapkan dapat menjadi tempat imago bertelur. Apabila telah menghasilkan telur, maka harus dilakukan pemindahan dan dikumpulkan pada gelas plastik lain. Perkembangan larva perlu diperhatikan secara terusmenurus. Larva yang telah menetas diberi pakan bayam segar alami dan dibersihkan dari kotoran. Sebagian larva yang terlihat ganti kulit dikumpulkan kembali dan diletakkan pada gelas plastik terpisah dari larva lainnya. Larva instar kedua pada generasi kedua itulah yang akan digunakan untuk pengujian dalam penelitian ini.

Pada penelitian ini insektisida nabati dibuat menggunakan metode fermentasi, beberapa langkah dalam pembuatannya sebagai berikut :

1. Persiapan bahan baku dari buah mengkudu matang sebanyak 500 gram, kemudian dimasukkan ke dalam blender.

2. Gula merah disiapkan sebanyak 50 gram, yang kemudian diencerkan menjadi $250 \mathrm{cc}$.

3. Persiapan bioaktivator berupa (EM4) sebanyak $50 \mathrm{cc}$, kemudian diencerkan bersamaan dengan gula merah yang telah dipersiapkan sebelumnya.

4. Bahan baku dimasukkan ke dalam ember plastik. Setelah itu, gula merah yang telah bercampur dengan EM4 dimasukkan ke dalam ember yang berisi bahan baku tersebut.

5. Air ditambah ke dalam ember plastik tersebut. Kemudian tutup dengan rapat.

6. Setelah itu tunggu selama 4-7 hari hingga terjadi proses fermentasi.

7. Menyaring hasil fermentasi pada hari ke 7, kemudian ampas dibuang dan cairannya telah dapat digunakan sebagai insektisida nabati.

Cara menghitung konsentrasi:

Konsentrasi $(\%)=\frac{\text { Dosis }}{\text { Vol. Semprot }} \times 100$

Contoh perhitungan ekstrak $40 \%$ yaitu:

Konsentrasi (40\%) $=\frac{40}{100} \times 200$

Pengujian dalam penelitian ini dilakukan dengan cara pencelupan daun (leaf dipping methods) atau disebut juga dengan metode residu dalam pakan. Larva $S$. litura yang telah mencapai instar kedua disiapkan dengan kondisi 
yang sehat dan diletakkan dalam wadah toples atau gelas plastik. Kemudian daun bayam dipersiapkan sebagai pakan yang telah diberi perlakuan dengan direndam dalam ekstrak buah mengkudu matang, sedangkan untuk perlakuan kontrol daun bayam direndam dalam aquades. Masing-masing perlakuan pada daun bayam yang telah direndam selama 10 detik kemudian dikeringkan pada suhu ruang. Pada pengujian penelitian ini terdapat 6 perlakuan yaitu: $\left(\mathrm{P}_{0}\right)$ 0\%.(kontrol), $\left(\mathrm{P}_{1}\right) 100 \%$ ekstrak buah mengkudu matang, $\left(\mathrm{P}_{2}\right)$ 80\% ekstrak buah mengkudu matang, $\left(\mathrm{P}_{3}\right) \quad 60 \%$ ekstrak buah mengkudu matang, $\left(\mathrm{P}_{4}\right)$ 40\% ekstrak buah mengkudu matang, $\left(\mathrm{P}_{5}\right) \quad 20 \%$ ekstrak buah mengkudu matang.

Daun bayam yang diberi perlakuan kemudian dimasukkan dalam gelas plastik. Pada masing-masing gelas diletakkan 11 ekor larva $S$. litura pada instar kedua generasi kedua dengan 6 perlakuan serta diulang sebanyak 4 kali. Setelah diberi perlakuan ekstrak buah mengkudu matang pada pakan larva, kemudian tunggu selama 24 jam. Untuk selanjutnya larva diberikan pakan tanpa perlakuan serta larva yang hidup dipisahkan hingga akhir instar IV.

Pengamatan dilakukan 24 jam setelah adanya perlakuan pada larva $S$. litura dengan menggunakan pakan yang telah dicelup dalam ekstrak buah mengkudu matang. Hal tersebut bertujuan untuk mengetahui jumlah $S$. litura yang mati (mortalitas) setelah diberi perlakuan. Jika terdapat $S$. litura yang tetap bertahan hidup hingga menjelang pembentukan stadium pra pupa maka perlakuan akan diberhentikan.

\section{HASIL DAN PEMBAHASAN}

\section{Pengaruh Ekstrak Buah Mengkudu pada Mortalitas $S$. litura}

Hasil analisis ragam (Tabel 1) menunjukkan bahwa aplikasi insektisida dengan ekstrak buah mengkudu matang berpengaruh pada mortalitas hama $S$. litura. Tingkat mortalitas $S$. litura terjadi karena adanya kandungan residu pada bahan baku insektisida alternatif berupa buah mengkudu matang serta perbedaan tingkat konsentrasi.

Tabel 1 menunjukkan bahwa pada perlakuan ekstrak $100 \%\left(\mathrm{P}_{1}\right)$, ekstrak $80 \% \quad\left(\mathrm{P}_{2},\right)$ dan ekstrak $60 \% \quad\left(\mathrm{P}_{3}\right)$ berpengaruh terhadap tingkat mortalitas $S$. litura tetapi antar pengaruh tidak berbeda. Sedangkan pada perlakuan kontrol $\left(\mathrm{P}_{0}\right)$, ekstrak $40 \%\left(\mathrm{P}_{4}\right)$, ekstrak $20 \%\left(\mathrm{P}_{5}\right)$ berpengaruh terhadap tingkat mortalitas $S$. litura serta pengaruhnya berbeda antar perlakuan.

Tabel 1. Rerata mortalitas pengaruh ekstrak buah mengkudu matang terhadap mortalitas S. litura

\begin{tabular}{cclc}
\hline Perlakuan & Konsentrasi & \multicolumn{2}{c}{ Rerata mortalitas (\%) } \\
\hline $\mathrm{P}_{1}$ & ekstrak $100 \%$ & 10,5 & $\mathrm{a}$ \\
\hline $\mathrm{P}_{2}$ & ekstrak $80 \%$ & 10 & $\mathrm{ab}$ \\
\hline $\mathrm{P}_{3}$ & ekstrak $60 \%$ & 9,5 & $\mathrm{bc}$ \\
\hline $\mathrm{P}_{4}$ & ekstrak $40 \%$ & 9 & $\mathrm{c}$ \\
\hline $\mathrm{P}_{5}$ & ekstrak $20 \%$ & 8 & $\mathrm{~d}$ \\
\hline $\mathrm{P}_{0}$ & kontrol $0 \%$ & 0 & $\mathrm{e}$ \\
\hline
\end{tabular}

Keterangan: Angka-angka yang diikuti huruf yang sama menunjukkan tidak berbeda nyata berdasarkan Uji Duncan pada taraf 5\%.

Tabel 2 menunjukkan bahwa ekstrak buah mengkudu matang selain mengakibatkan kematian juga dapatmenghambat perkembangan larva
S. litura. Berdasarkan hasil di atas diketahui bahwa pengaruh perlakuan insektisida dengan ekstrak buah mengkudu matang terhadap 
perkembangan larva $S$. litura instar IIIV (prapupa) dengan konsentrasi 20\%$100 \%$ adalah 10,13 hari sampai dengan 14,13 hari tidak menunjukkan penghambatan terhadap perkembangan larva. Lama perkembangan larva tidak menunjukkan pengaruh terhadap perlakuan kontrol $\left(\mathrm{P}_{0}\right)$. Buah mengkudu memiliki Flavonoid termasuk dalam golongan yang berperan sebagai racun penghambat metabolisme dan sistem saraf yang bekerja perlahan (Septian et al. 2013). Makanan alternatif dari $S$. litura yang telah diberi perlakuan dengan ekstrak buah mengkudu matang akan berdampak merusak aktivitas enzim-enzim dan proses pencernaan tidak optimum bahkan terjadi kematian, hal tersebut dikarenakan adanya senyawa aktif.

Tabel 2. Lama perkembangan larva $S$. litura akibat perlakuan ekstrak buah mengkudu matang

\begin{tabular}{lcc}
\hline Perlakuan & $\mathrm{N}$ & $\begin{array}{c}\text { Lama perkembangan } \\
\text { instar II-IV (hari } \pm \mathrm{Sd} \text { ) }\end{array}$ \\
\hline kontrol & 44 & $14,13 \pm 0,00$ \\
\hline ekstrak100\% & 2 & $14,10 \pm 0,58$ \\
\hline ekstrak80\% & 4 & $13,75 \pm 0,00$ \\
\hline ekstrak60\% & 6 & $10,17 \pm 0,58$ \\
\hline ekstrak40\% & 8 & $10,13 \pm 0,82$ \\
\hline ekstrak20\% & 12 & $13,43 \pm 0,82$ \\
\hline
\end{tabular}

Keterangan:

$\mathrm{N}$ : Jumlah larva yang hidup setelah diberi perlakuan

Sd: Standar deviasi

Pada Tabel 5 menunjukkan bahwa waktu kematian larva $S$. litura yang paling cepat terdapa pada perlakuan dengan ekstrak buah mengkudu matang $100 \%\left(\mathrm{P}_{1}\right)$. Kecepatan waktu kematian larva yang paling cepat yaitu pada $\mathrm{P}_{1}$ konsentrasi $100 \% \quad\left(\mathrm{P}_{1}\right)$. Sedangkan kematian larva yang paling lambat yaitu pada konsentrasi $20 \%\left(\mathrm{P}_{5}\right)$ dan secara statistik memiliki nilai yang berbeda nyata. Peningkatan konsentrasi ekstrak buah mengkudu matang menyebabkan kematian larva yang semakin cepat terjadi (Heviyanti et al. 2016). Senyawa yang menempel dan terakumulasi ke dalam tubuh larva $S$. litura akan berdampak mempercepat kematian sebanyak $50 \%$. Waktu yang dibutuhkan dalam mematikan larva sebanyak 50\% serangga uji disebabkan karena aplikasi insektisida nabati dengan konsentrasi yang tinggi (Rusandi et al. 2016).

Tabel 3. Data mortalitas S. litura 1 HSA (akumulasi)

\begin{tabular}{lccc}
\hline \multicolumn{1}{c}{ Perlakuan } & Mortalitas Jumlah & $\begin{array}{c}\text { Mortalitas } \\
(\%)\end{array}$ \\
\hline $\mathrm{P}_{0}$ kontrol & 0 & 0 & 0,00 \\
\hline $\mathrm{P}_{1}$ ekstrak 100\% & 8 & 8 & 18,18 \\
\hline $\mathrm{P}_{2}$ ekstrak $80 \%$ & 1 & 1 & 2,27 \\
\hline $\mathrm{P}_{3}$ ekstrak $60 \%$ & 6 & 6 & 13,64 \\
\hline $\mathrm{P}_{4}$ ekstrak 40\% & 3 & 3 & 6,82 \\
\hline $\mathrm{P}_{5}$ ekstrak 20\% & 4 & 4 & 9,09 \\
\hline
\end{tabular}

Keterangan: Hari Setelah Aplikasi (HSA)

Tabel 4. Data mortalitas S. litura 2 HSA (akumulasi)

\begin{tabular}{lccc}
\hline \multicolumn{1}{c}{ Perlakuan } & Mortalitas & Jumlah & $\begin{array}{c}\text { Mortalitas } \\
(\%)\end{array}$ \\
\hline $\mathrm{P}_{0}$ kontrol & 0 & 0 & 0,00 \\
\hline $\begin{array}{l}\mathrm{P}_{1} \text { ekstrak } \\
100 \%\end{array}$ & 8 & 16 & 36,36 \\
\hline $\mathrm{P}_{2}$ ekstrak 80\% & 10 & 11 & 25,00 \\
\hline $\mathrm{P}_{3}$ ekstrak 60\% & 6 & 12 & 27,27 \\
\hline $\mathrm{P}_{4}$ ekstrak 40\% & 7 & 10 & 22,73 \\
\hline $\mathrm{P}_{5}$ ekstrak 20\% & 4 & 8 & 18,18 \\
\hline \multicolumn{4}{l}{ Keterangan: Hari Setelah Aplikasi (HSA) }
\end{tabular}

Tabel 5. Data mortalitas S. litura 3 HSA (akumulasi)

\begin{tabular}{lccc}
\hline Perlakuan & Mortalitas Jumlah & $\begin{array}{c}\text { Mortalitas } \\
(\%)\end{array}$ \\
\hline $\mathrm{P}_{0}$ kontrol & 0 & 0 & 0,00 \\
\hline $\mathrm{P}_{1}$ ekstrak 100\% & 7 & 23 & 52,27 \\
\hline $\mathrm{P}_{2}$ ekstrak $80 \%$ & 5 & 16 & 36,36 \\
\hline $\mathrm{P}_{3}$ ekstrak 60\% & 6 & 18 & 40,91 \\
\hline $\mathrm{P}_{4}$ ekstrak 40\% & 5 & 15 & 34,09 \\
\hline $\mathrm{P}_{5}$ ekstrak 20\% & 6 & 14 & 31,82 \\
\hline
\end{tabular}

Keterangan: Hari Setelah Aplikasi (HSA)

Berdasarkan Tabel di atas (3, 4 dan 5) bahwa perlakuan konsentrasi $100 \%$ ekstak buah mengukudu matang $\left(\mathrm{P}_{1}\right)$, lebih cepat dalam mematikan larva. Perlakuan pada $100 \%\left(\mathrm{P}_{1}\right)$ memberikan pengaruh mortalitas yang tinggi dibandingkan dengan jumlah mortalitas yang terjadi pada $80 \%\left(\mathrm{P}_{2}\right), 60 \%\left(\mathrm{P}_{3}\right)$, 
$40 \% \quad\left(\mathrm{P}_{4}\right)$, dan $20 \%\left(\mathrm{P}_{5}\right)$. Tabel 5 menunjukkan presentase mortalitas larva S. litura perlakuan $100 \%$ ekstrak buah mengkudu matang $\left(\mathrm{P}_{1}\right)$ sebanyak 52,27 $\%$ dalam jangka waktu 3 hari setelah aplikasi. Kandungan senyawa kimia yang ada pada buah mengkudu menimbulkan kematian terhadap larva $S$. litura sehingga keefektifan perlakuan dengan $100 \%$ ekstrak buah mengkudu matang dapat dimanfaatkan sebagai insektisida nabati.

Nilai mortalitas $\mathrm{P}_{1}$ ekstrak $100 \%$ pada (Tabel 5) diperoleh dengan cara perhitungan yaitu:

Nilai mortalitas pada (Tabel 5):

$$
=\frac{\sum \text { mortalitas }}{\sum \text { larva dalam perlauan }} \times 100 \%
$$

Nilai mortalitas $\mathrm{P}_{1}$ pada (Tabel 5)

$$
\begin{aligned}
& =\frac{23}{44} \times 100 \% \\
& =52,27 \%
\end{aligned}
$$

\section{SIMPULAN}

Berdasarkan hasil penelitian yang diperoleh dapat disimpulkan bahwa insektisida nabati berbahan baku ekstrak buah mengkudu matang sangat berpotensi mengendalikan hama S. litura dan konsentrasi terbaik ekstrak buah mengkudu adalah konsentrasi 100\% tanpa campuran air.

\section{UCAPAN TERIMA KASIH}

Penulis mengucapkan terima kasih terkhusus kepada Dosen Pembimbing dalam penyusunan dan terimakasih juga kepada seluruh Dosen Jurusan Budidaya
Tanaman Perkebunan Politeknik Negeri Lampung yang telah membantu dan memberikan saran dalam penelitian ini.

\section{DAFTAR PUSTAKA}

Heviyanti, Maria, Husni, Alfian Rusdy. 2016. Efektifitas Ekstrak Biji Mahoni (Swietenia Mahogani Jacq.) Terhadap Mortalitas Dan Rata-Rata Waktu Kematian Larva Plutella Xylostella Pada Tanaman Sawi. Agrosamudra 3(1): 27- 38.

Lestari, Sri, Hery Ambarningrum, Trisnowati Budi Pratiknyo. 2013. Tabel Hidup Spodoptera Litura Fabr. Dengan Pemberian Pakan Buatan Yang Berbedae. Jurnal Sain Veteriner 31(2): 166- 67.

Rusandi, Rio, M Mardhiansyah, Tuti Arlita. 2016. Pemanfaatan Ekstrak Biji Mahoni Sebagai Pestisida Nabati Untuk Mengendalikan Hama Ulatgrayak (Spodoptera Litura F.) Pada Pembibitan Acacia Crassicarpa A. Cunn. Ex Benth. Jom Faperta UR 3(1): $1-7$.

Septian, Rodhiyah Eka, Isnawati, Evie Ratnasari. 2013. Pengaruh Kombinasi Ekstrak Biji Mahoni Dan Batang Brotowali Terhadap Mortalitas Dan Aktivitas Makan Ulat Grayak Pada Tanaman Cabai Rawit. LenteraBio 2(1): 107- 12.

Thamrin, M, S Asikin, M Willis. 2013. Tumbuhan Kirinyu Chromolaena Odorata (L) (Asteraceae: Asterales) Sebagai Insektisida Nabati Untuk Mengendalikan Ulatgrayak Spodoptera Litura.32(3): 112- 21.

Wiratno, Siswanto, I.M. Trisawa. 2013. Perkembangan Penelitian, Formalitas, Dan Pemanfaatan Pestisida Nabati Research Progress, Formulation, and Utilization of Botanical Pesticide.32(4): 150- 55. 